\title{
Isolation and evaluation of bacterial endophytes against Sclerospora graminicola (Sacc.) Schroet, the causal of pearl millet downy mildew
}

\author{
Pooja Sangwan ${ }^{1}$, Kushal Raj $^{*}$, Leela Wati ${ }^{2}$ and Anil Kumar ${ }^{1}$
}

\begin{abstract}
Background: Pearl millet remains prone to many diseases; among them downy mildew caused by Sclerospora graminicola (Sacc.) Schroet is economically more important. The use of endophytic bacteria for management of downy mildew of pearl millet as eco-friendly approach is increasing attention as sustainable alternative to pesticides. The objective of the present study was to isolate endophytic bacteria from roots of pearl millet cultivars and assess for biocontrol activity against Sclerospora graminicola.

Results: Thirty pearl millet root bacterial endophytes (PMRBEs) were isolated and screened in vitro for biocontrol activities such as: siderophore production, hydrogen cyanide (HCN) production and 1-amino cyclopropane-1-carboxylate (ACC) deaminase activity. Sixteen isolates possessed siderophore production potential, 3 isolates were found to be HCN producers, and $30 \%$ of the bacterial endophytes showed a good growth on ACC supplemented plates. On the basis of biocontrol activities, promising endophyte PMRBE6 was selected for seed treatment as well as a foliar spray to manage downy mildew of pearl millet in screen house experiment. The isolate PMRBE6 was found to be effective in managing downy mildew disease. Grain yield, test weight, plant height and average number of productive tillers were found to be maximum on inoculation of seeds of different pearl millet cultivars with PMRBE6, and the results were statistically significant as compared to control.
\end{abstract}

Conclusions: On the basis of biochemical characterization and partial $16 \mathrm{~S}$ rRNA sequencing, the isolate PMRBE6 was identified as Bacillus subtilis strain PD4 (Accession no. MN400209). Pearl millet root bacterial endophyte (PMRBE6) exhibiting biocontrol activities could be exploited in friendly, sustainable organic agriculture.

Keywords: Biocontrol, Sclerospora graminicola, Downy mildew, Endophyte, Pearl millet, Siderophore

\section{Background}

Pearl millet [Pennisetum glaucum (L.) R.Br. Syn. Pennisetum americanum (L.) Leeke] is a short duration rain fed crop mostly grown in low fertile soil, able to thrive well in the rainfall as low as $250 \mathrm{~mm}$. The crop is cultivated for grain as well as fodder, and the fodder of this crop is

\footnotetext{
${ }^{*}$ Correspondence: kushalraj@hau.ac.in

${ }^{1}$ Department of Plant Pathology, College of Agriculture, CCS Haryana

Agricultural University, Hisar, Haryana Pin 125 004, India

Full list of author information is available at the end of the article
}

of excellent quality. This is the oldest cultivated crops of Asian and African countries due to its adaptability under very wide range of agro-climatic conditions. Pearl millet remains prone to many diseases; among them downy mildew is economically more important. Sclerospora graminicola (Sacc.) Schroet, incitant of downy mildew of pearl millet, is an obligate, pathogenic fungus belonging to family Peronosporaceae, order Peronosporales.

The use of endophytic bacteria for managing pathogenic fungi and bacteria is receiving increasing attention as sustainable alternative to pesticides, etc. Their 
application can reduce the use of chemical fertilizers, pesticides and effectively alleviate environmental pollution. Endophytes colonize the internal tissues of plants without causing any visible harm to plants. Endophytic bacteria have been found virtually in every plant, where they colonize internal tissues of their host plants and can form different relationships like symbiotic, mutualistic, commensalistic and trophobiotic. They influence plant growth by producing phytohormones such as indole acetic acid, cytokinins and gibberellins (Sandhya et al. 2017). The metabolic activities of endophytes can help in phosphate solubilization (Prakash and Arora 2019), atmospheric nitrogen fixation and reduce ethylene production by 1-amino cyclopropane-1-carboxylate (ACC) deaminase activity (Souza et al. 2015). Some endophytes inhibit pathogenic micro-organisms by producing siderophores (Wang et al. 2013) and antimicrobial metabolites (Liu et al. 2016). Endophytic bacteria also secrete alkaloids, steroids and enzymes which protect plants against pathogenic invasion (Banik et al. 2016). Bacterial endophytes are promising alternative for plant disease control and have potential to be used in environmental restoration and agriculture. Endophytic bacteria are ubiquitously distributed in most plant species either through their active colonization or as latent residents in plant tissues. In contrast to phytopathogenic bacteria, they do not cause any disease symptoms; indeed, they can promote plant growth (Berg 2009). Endophytic microorganisms can vary based on plant source, age, type of tissue, season of sampling and environment. Endophytes have been reported to be isolated from all plant tissues. In most of the plants, roots have the higher endophytic population as compared to above-ground tissues (Rosenblueth and Martínez-Romero 2004); and their population decreases progressively from the stem to the leaves (Quadt-Hallman et al. 1997).

Endophytes influence plant growth after establishment in a plant and provide resistance. Endophytic bacteria on the basis of their effect on host plants can be divided into 3 groups, viz. plant-growth promoting, plant-growth inhibiting and plant-growth neutral (Bai et al. 2002). The plant growth promoting bacteria can be used to manage plant pathogens, insects and nematodes through various mechanisms (Ryan et al. 2008). Siderophore production is one of the traits that make microorganisms successful competitors in various environments and facilitate plant bacterial association as well as colonization of roots, stem and leaves thus, make iron unavailable to pathogenic microorganisms.

The usage of endophytic bacteria for management of downy mildew of pearl millet aimed to be an ecofriendly approach. The objective of the present study was to isolate endophytic bacteria from roots of pearl millet cultivars and assess for biocontrol activity against Sclerospora graminicola within the framework of integrated plant disease management (IDM).

\section{Methods \\ Isolation of bacterial endophytes}

Roots of pearl millet cultivars, viz. HHB226, HHB67 Imp and $7042 \mathrm{~S}$, were collected after harvesting of the pearl millet crop from infested plots of Plant Pathology experimental area of CCS Haryana Agricultural University Hisar with latitude $29^{\circ} 14^{\prime} \mathrm{N}$ and longitude of $75^{\circ} 70^{\prime}$ E. Roots were washed with running tap water and then, surface sterilized sequentially in $75 \%(\mathrm{v} / \mathrm{v})$ ethanol for $2 \mathrm{~min}, 2.6 \%(\mathrm{w} / \mathrm{v})$ sodium hypochlorite solution for $5 \mathrm{~min}$ and $75 \%(\mathrm{v} / \mathrm{v})$ ethanol for $1 \mathrm{~min}$. Finally, roots were thoroughly washed 6 times with sterile distilled water, and the final wash was spread on nutrient agar (NA) plates and incubated at $28 \pm 2{ }^{\circ} \mathrm{C}$ for 3 days as sterility check. For isolation of bacterial endophytes, 1 -g root sample was crushed in pestle and mortar with $10 \mathrm{ml}$ sterile distilled water to get homogenous paste and allowed to settle down for $20 \mathrm{~min}$. The supernatant was diluted, and approximately $10 \mu \mathrm{l}$ was spread on NA plates and incubated at $28 \pm 2{ }^{\circ} \mathrm{C}$ for 3 days. Bacterial colonies considered as endophytes were characterized according to different visual observations and finally purified using streak plate technique. The bacterial colonies were maintained at $4 \pm 1{ }^{\circ} \mathrm{C}$ for further studies.

\section{Screening of endophytic bacteria for biocontrol activity}

Bacterial endophytes were tested for biocontrol activities, viz. siderophore production, $\mathrm{HCN}$ production, and $\mathrm{ACC}$ deaminase activity.

\section{Siderophore production}

Pearl millet root bacterial endophytes were evaluated for siderophore production on chrome azurol S assay plates (Schwyn and Neilands, 1987). Five $\mu$ inoculant of each log phase grown bacterial culture was spotted on chrome azurol agar plates and incubated at $28 \pm 2{ }^{\circ} \mathrm{C}$ for 5 days. The presence of siderophore was indicated by decolourization of the blue-coloured ferric dye complex, resulting in yellow halo zones around the colonies.

\section{HCN production}

$\mathrm{HCN}$ production potential of pearl millet root bacterial endophyte was detected using alkaline picrate filter paper (Alstrom and Burns 1989). The inoculum of different bacterial endophytes was prepared by inoculation of 48-h-old culture from nutrient agar slants into freshly prepared King's B broth. The production $\mathrm{HCN}$ was detected after $72 \mathrm{~h}$ of incubation at $28 \pm 2{ }^{\circ} \mathrm{C}$, using picrate $/ \mathrm{Na}_{2} \mathrm{CO}_{3}$ paper fixed underside of test tube. A change 


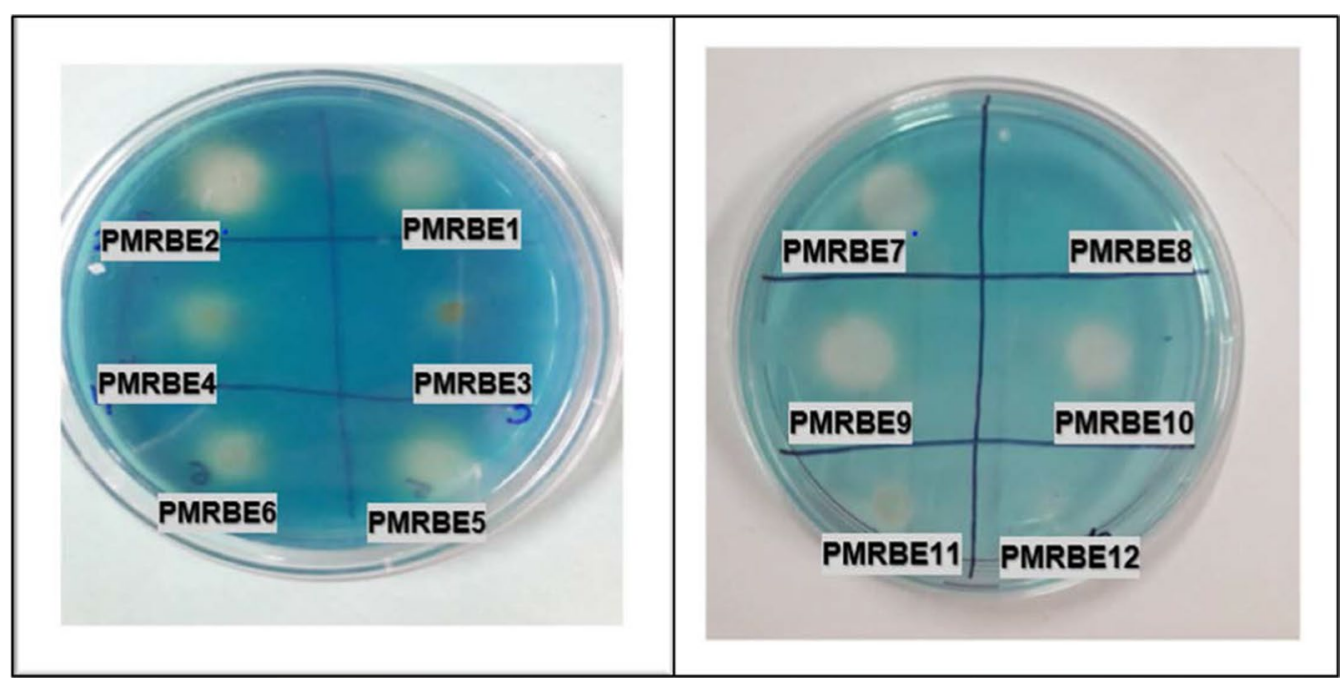

Fig. 1 Siderophore production ability of pearl millet root bacterial endophytes

of colour from yellow to brown, brown, reddish brown was recorded as indication of weak, moderate or strong cyanogenic potential.

\section{ACC deaminase activity}

1-aminocyclo propane-1carboxylate (ACC) utilization as indicator of ACC deaminase activity of pearl millet root bacterial endophytes was assayed by inoculating 48-h-old bacterial culture on minimal medium agar plates supplemented with $2 \mathrm{mM}$ ACC/ammonium sulphate (Penrose and Glick 2003). Growth on ACC and ammonium sulphate supplemented medium plates was recorded after 5 days of incubation at $28 \pm 2{ }^{\circ} \mathrm{C}$. The bacterial isolates showing good growth on ACC supplemented plates indicated the efficiency of ACC deaminase activity, while growth on ammonium sulphate was used as control. The isolate PMRBE6 showing all growth promoting characters was selected for morphological, biochemical characterization and screen house experiment.

\section{Morphological and Biochemical characterization}

Pearl millet root bacterial endophyte PMRBE6 was observed for morphological characters, viz. cell shape, colour, colony morphology and Gram reaction. Biochemical characterization was done as per procedure described in Bergey's manual of Determinative Bacteriology (Holt et al. 1994).

\section{Molecular characterization of pearl millet root bacterial endophyte}

Promising bacterial endophyte PMRBE6 retrieved from pearl millet roots was identified on the basis of partial $16 \mathrm{~S}$ rRNA sequencing. The genomic DNA of endophytic bacterium was isolated using cetyltrimethyl ammonium bromide (CTAB) method and amplified using forward primer $5^{\prime}$ AGA GTT TGA TCC CTC AG $3^{\prime}$ and reverse primer $5^{\prime}$ AAG GAG GTG ATC CAG CCG CA 3'. The PCR reaction consisted of $1 \mu \mathrm{l}$ of template DNA, $400 \mathrm{ng}$ of $16 \mathrm{~S}$ forward primer, $400 \mathrm{ng}$ of $16 \mathrm{~S}$ reverse primer, $4 \mu \mathrm{l}$ dNTP ( $2.5 \mathrm{mM}$, each), $10 \mu \mathrm{l} 10 \times$ Taq DNA polymerase Assay Buffer and $1 \mu \mathrm{l}$ Taq DNA Polymerase Enzyme (3U/ $\mu \mathrm{l})$. Final volume of reactive mixture was adjusted to $100 \mu \mathrm{l}$. PCR was carried out in a thermocycler with an initial denaturation for $5 \mathrm{~min}$ at $95{ }^{\circ} \mathrm{C}$, then 35 cycles of $30 \mathrm{~s}$ at $94{ }^{\circ} \mathrm{C}, 15 \mathrm{~s}$ of $50{ }^{\circ} \mathrm{C}, 1.30 \mathrm{~min}$ at $72{ }^{\circ} \mathrm{C}$ and a final extension for $7 \mathrm{~min}$ at $72{ }^{\circ} \mathrm{C}$. The amplified PCR products were analysed by electrophoresis on $1 \%$ agarose gel with Tris-acetate-EDTA (TAE) buffer and visualized on a gel documentation system. The partial sequence of 16S rRNA gene of promising bacterial endophyte was obtained after sequencing from Chromous BioTech Pvt. Ltd., Bangalore, and phylogenetic tree was prepared by neighbour joining of BLAST programme. The identified gene sequence was submitted to NCBI GenBank, and accession number was obtained.

\section{Evaluation of pearl millet root bacterial endophyte for plant growth promoting ability under screen house conditions}

Bacterial endophyte PMRBE6 was tested for the management of pearl millet downy mildew under screen house conditions during the fall of 2017 and 2018. The experiment was conducted with 5 treatments in a completely randomized design and with 4 replications of each 
Table 1 Biocontrol activities of pearl millet root bacterial endophytes

\begin{tabular}{|c|c|c|c|}
\hline Isolate & $\begin{array}{l}\text { Siderophore } \\
\text { production }\end{array}$ & HCN Production & ACC utilization \\
\hline PMRBE1 & + & - & ++ \\
\hline PMRBE2 & + & - & + \\
\hline PMRBE3 & - & - & + \\
\hline PMRBE4 & + & - & ++ \\
\hline PMRBE5 & + & - & + \\
\hline PMRBE6 & + & + & +++ \\
\hline PMRBE7 & + & - & +++ \\
\hline PMRBE8 & - & - & + \\
\hline PMRBE9 & + & - & +++ \\
\hline PMRBE10 & + & - & +++ \\
\hline PMRBE11 & - & - & ++ \\
\hline PMRBE12 & - & - & + \\
\hline PMRBE13 & - & - & + \\
\hline PMRBE14 & - & - & +++ \\
\hline PMRBE15 & - & - & + \\
\hline PMRBE16 & + & - & ++ \\
\hline PMRBE17 & + & - & ++ \\
\hline PMRBE18 & + & - & + \\
\hline PMRBE19 & - & - & +++ \\
\hline PMRBE20 & + & - & + \\
\hline PMRBE21 & - & - & ++ \\
\hline PMRBE22 & - & - & + \\
\hline PMRBE23 & + & - & + \\
\hline PMRBE24 & - & - & +++ \\
\hline PMRBE25 & + & + & +++ \\
\hline PMRBE26 & + & - & +++ \\
\hline PMRBE27 & - & - & + \\
\hline PMRBE28 & + & + & ++ \\
\hline PMRBE29 & - & - & ++ \\
\hline PMRBE30 & - & - & - \\
\hline
\end{tabular}

+++ : Good growth, ++ : moderate growth, + : poor growth, - : no growth

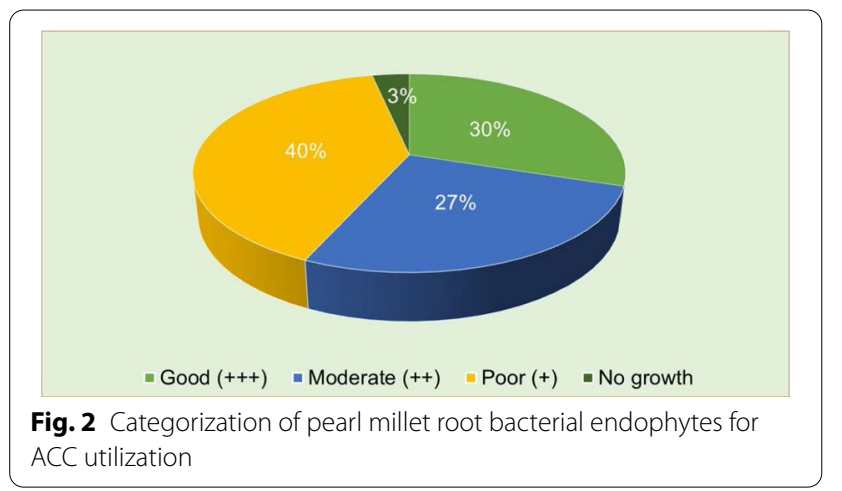

treatment. Earthen pots filled with $5 \mathrm{~kg}$ of sterilized soil (sand + FYM mix) were mixed with oosporic material.

Seeds of pearl millet cultivars, viz. HHB 226 (Resistant), HHB-67 Imp (Moderately resistant) and 7042S (Highly susceptible) were surface sterilized with $0.2 \%$ sodium hypochlorite for 2-3 min, later washed with distilled water several times and dried using sterile blotter paper. Seeds were inoculated by PMRBE6 @ $5 \mathrm{ml} / \mathrm{kg}$ seed, metalaxyl @ $6 \mathrm{~g} / \mathrm{kg}$ seeds and foliar spray of selected endophyte PMRBE6 @ $10^{8} \mathrm{ml}^{-1}$ till run off and chemical metalaxyl MZ @ 0.25\% was given on 2-week-old seedling. Suitable control was maintained as check in which seeds were surface sterilized and kept uninoculated. Five seeds were sown in each pot, and after germination, only 2 plantlets in each pot were maintained. The observations on downy mildew disease incidence at 30 and 60 days after sowing (DAS), plant height, average number of productive tillers/plant, yield as well as test weight were recorded. Statistical analysis was carried out through online software https://www.hau.ac.in/page/o-p-stat.

\section{Results}

Isolation of pearl millet root bacterial endophytes and their evaluation for biocontrol activities

A total of 30 pearl millet root bacterial endophytes of various morphology (PMRBE1-PMRBE30) were retrieved from roots of pearl millet raised during the fall of 2016 and 2017. All endophytic bacterial isolates were screened for biocontrol activity by assessing their ability for siderophore production, $\mathrm{HCN}$ production and ACC utilization.

\section{Siderophore production}

Out of 30 pearl millet root bacterial endophytes, 16 isolates, viz. PMRBE1, PMRBE2, PMRBE4, PMRBE5, PMRBE6, PMRBE7, PMRBE9, PMRBE10, PMRBE16, PMRBE17, PMRBE18, PMRBE20, PMRBE23, PMRBE25, PMRBE26 and PMRBE28, showed development of orange halo zone on CAS medium amended with ferric chloride indicating siderophore production ability (Fig. 1).

\section{Hydrogen cyanide production}

Among 30 pearl millet root bacterial endophytes screened for $\mathrm{HCN}$ production, change in the colour of soaked alkaline picrate filter paper from yellow to brown was observed in isolates PMRBE6, PMRBE25 and PMRBE28.

\section{1-aminocyclopropane-1-carboxylate (ACC) utilization} On ACC supplemented plates, out of thirty endophytic bacterial isolates, nine isolates (30\%), viz. PMRBE6, 

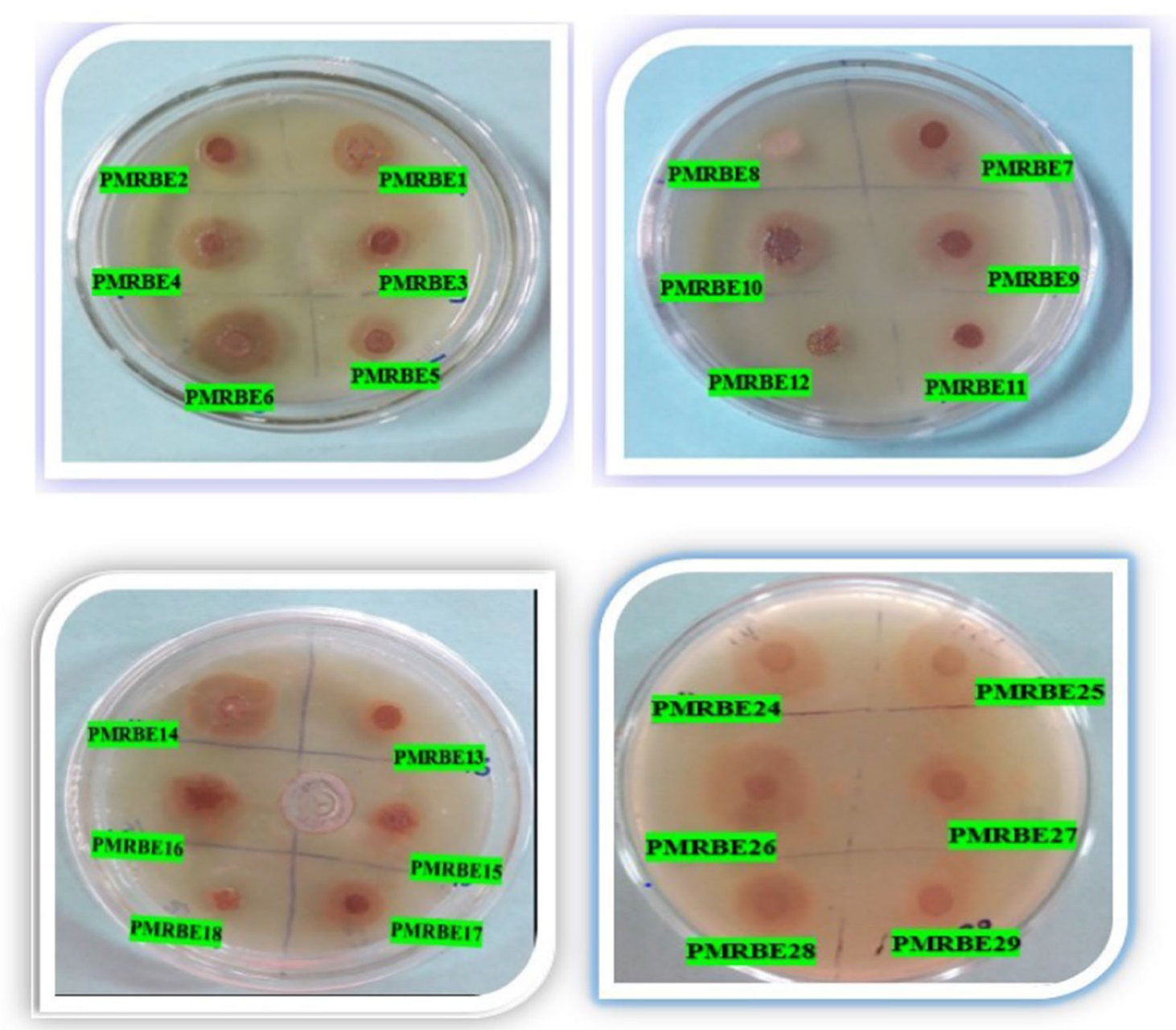

Fig. 3 ACC utilization by pearl millet root bacterial endophytes

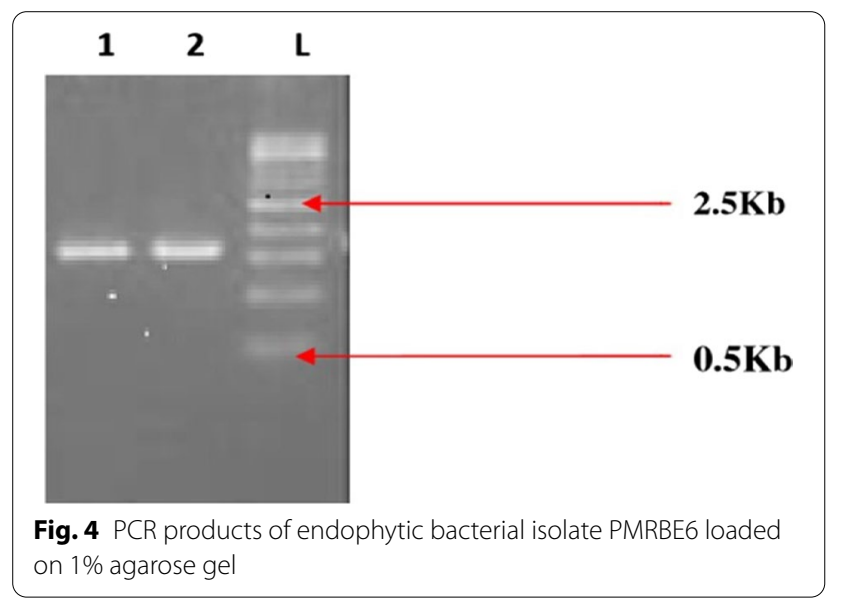

PMRBE7, PMRBE9, PMRBE10, PMRBE14, PMRBE19, PMRBE24, PMRBE25 and PMRBE26, showed good growth, eight isolates (27\%), viz. PMRBE1, PMRBE4, PMRBE11, PMRBE16, PMRBE17, PMRBE21, PMRBE28 and PMRBE29, showed moderate growth, 12 isolates (40\%) showed poor growth and the isolate PMRBE30 (3\%) showed no growth (Table 1, Figs. 2, 3).

\section{Morphological and biochemical characterization of promising pearl millet root bacterial endophyte, PMRBE6}

Morphological characterization of PMRBE6 revealed that bacterium was fast growing, rod shaped with whitish, circular, smooth and raised colony on nutrient agar medium. Gram reaction revealed that endophyte PMRBE6 was Gram positive. 


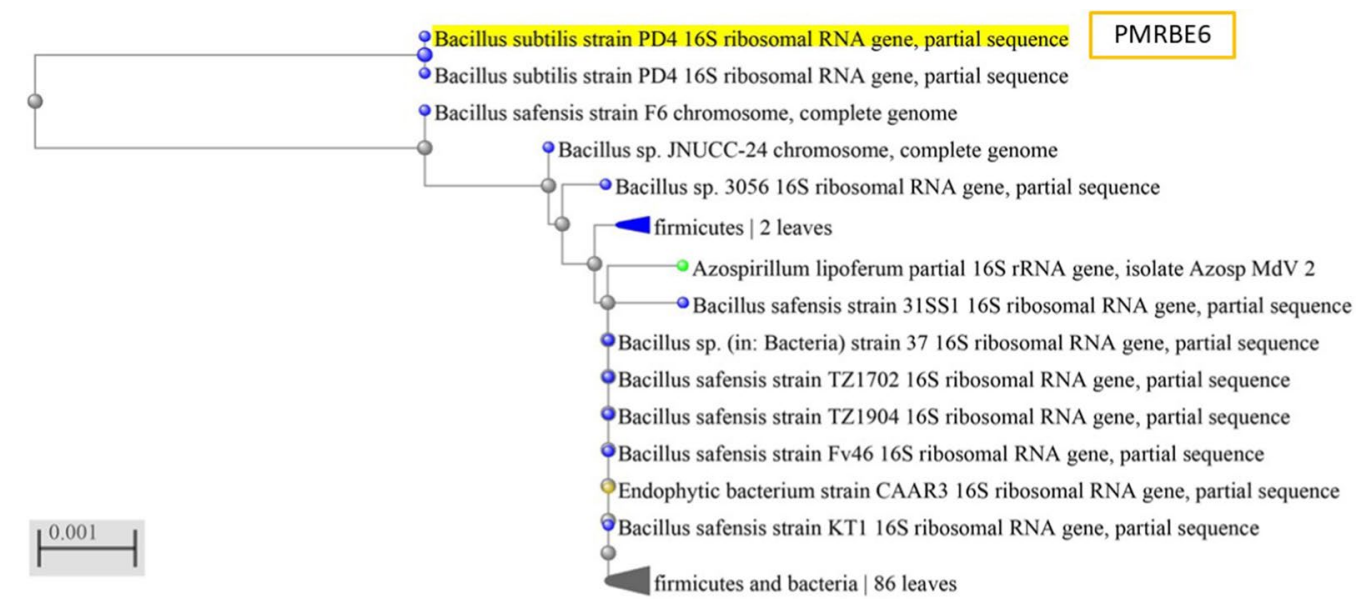

Fig. 5 Phylogenetic tree of endophytic isolate PMRBE6

\section{Molecular characterization of pearl millet root bacterial endophyte PMRBE6}

Sequencing of the 16S rRNA gene is an important tool for identification and characterization of bacteria. In the present study, the promising pearl millet root bacterial endophyte PMRBE6 showed 97.6\% similarity with Bacillus subtilis strain PD4 (Accession no. MN400209) on the basis of 16SrRNA sequencing (Figs. 4, 5).

\section{Effect of pearl millet root bacterial endophyte on downy mildew incidence under screen house conditions}

On the basis of biocontrol activities promising endophyte, PMRBE6 was selected for seed treatment as well as foliar spray to manage downy mildew in pearl millet cultivars, HHB 226, HHB-67 Imp and 7042S. Downy mildew incidence at 30 days after sowing (DAS) was recorded as nil on inoculation of HHB 226 seeds with isolate PMRBE6, with metalaxyl MZ, seed treatment + foliar spray with bacterial isolate PMRBE6 and seed treatment + foliar spray with metalaxyl MZ, while it was $50 \%$ in control. In HHB67 Imp, no disease was recorded on seed treatment with metalaxyl + foliar spray with metalaxyl MZ. In $7042 \mathrm{~S}$ minimum disease incidence (31.3\%) was observed on seed treatment with isolate PMRBE6, seed treatment + foliar spray with bacterial isolate PMRBE6, seed treatment with metalaxyl+foliar spray with metalaxyl MZ, while in control disease incidence it was $93.75 \%$.

Downy mildew incidence at 60 days after sowing was recorded nil in HHB226 on inoculation of seeds with PMRBE6 and also was nil on seed treatment + foliar spray with isolate PMRBE6 and seed treatment + foliar spray with metalaxyl MZ. In HHB 67 Imp, it was $6.3 \%$ on inoculation with isolate PMRBE6, on seed treatment + foliar spray with isolate PMRBE6 and on seed treatment + foliar spray with metalaxyl MZ. In 7042 $\mathrm{S}$ cultivar, seed treatment with bacterial isolate PMRBE6 and seed treatment + foliar spray with isolate PMRBE6 recorded minimum disease incidence of $50 \%$ (Table 2).

\section{Effect of pearl millet root bacterial endophyte PMRBE6} on growth attributes under screen house conditions PMRBE6 significantly affected average number of productive tillers/plant and height of pearl millet cultivars (Table 3). In HHB 226 and HHB67 Imp, average number of productive tillers was maximum (2.8 tillers/plant and 2.7 tillers/plant) on inoculation of seeds + foliar spray with isolate PMRBE6 and in $7042 \mathrm{~S}$ average number of productive tillers/plant was 1.3 on inoculation of seeds of $7042 \mathrm{~S}$ with isolate PMRBE6 as compared to control (0.0).

Maximum plant heights of 164.4, 151.0 and $131.7 \mathrm{~cm}$ in HHB226, HHB67 Imp and $7042 \mathrm{~S}$, respectively, were recorded on seed treatment with isolate PMRBE6 as compared to $135.0,127.2$ and $121.3 \mathrm{~cm}$, respectively, in control.

\section{Impact of pearl millet root bacterial endophyte PMRBE6 on yield attributes under screen house conditions} Grain yield of HHB226 was maximum (78.7 g/plant) on seed treatment with metalaxyl+foliar spray with metalaxyl MZ @ 0.25\%, which was statistically at par to $78.3 \mathrm{~g} /$ plant on seed treatment + foliar spray with isolate PMRBE6. In HHB67 Imp and $7042 \mathrm{~S}$, maximum yield (78.3 g/plant and $42.7 \mathrm{~g} /$ plant) was recorded on seed treatment + foliar spray with isolate PMRBE6, which was significantly higher than control. Test weight of HHB226 seeds was $8.9 \mathrm{~g}$ on seed treatment + foliar spray with isolate PMRBE6. Seeds of HHB67 Imp and $7042 \mathrm{~S}$ had 


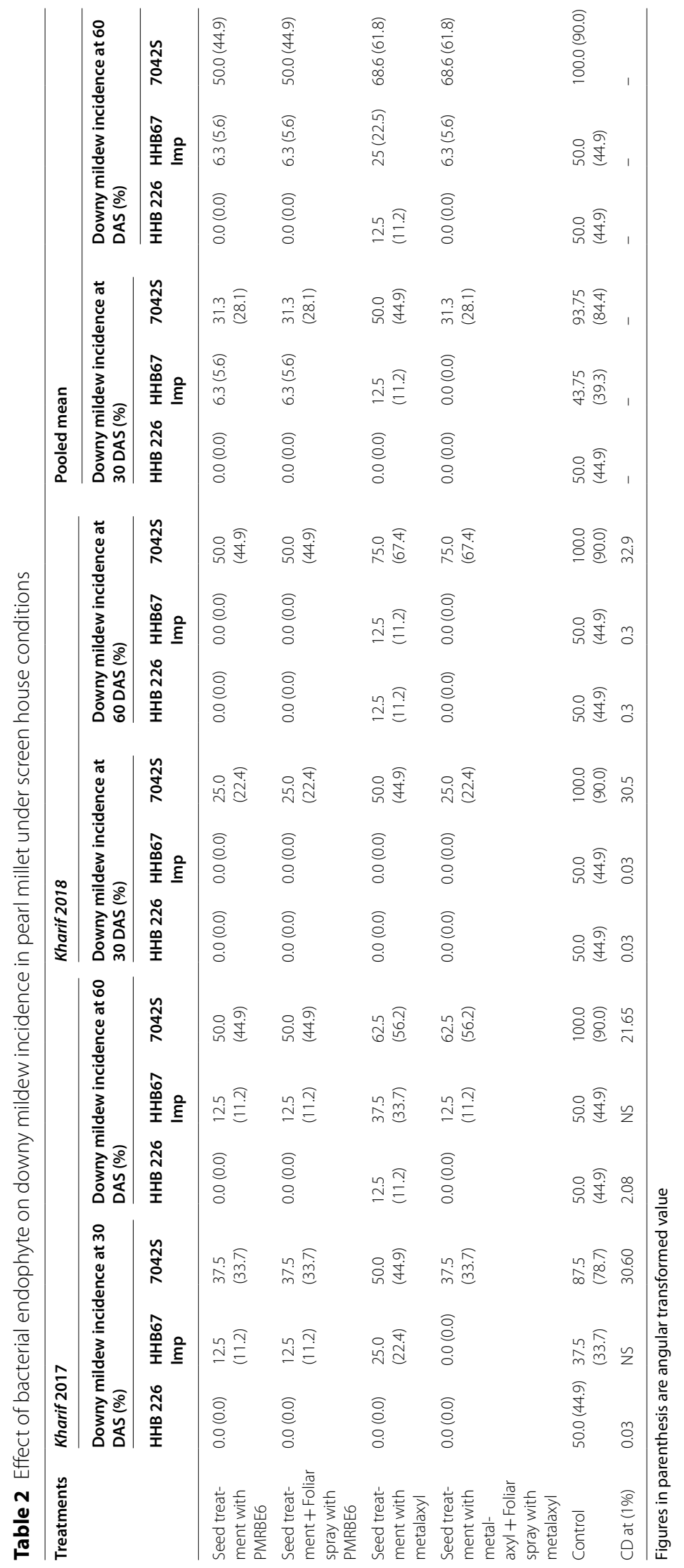




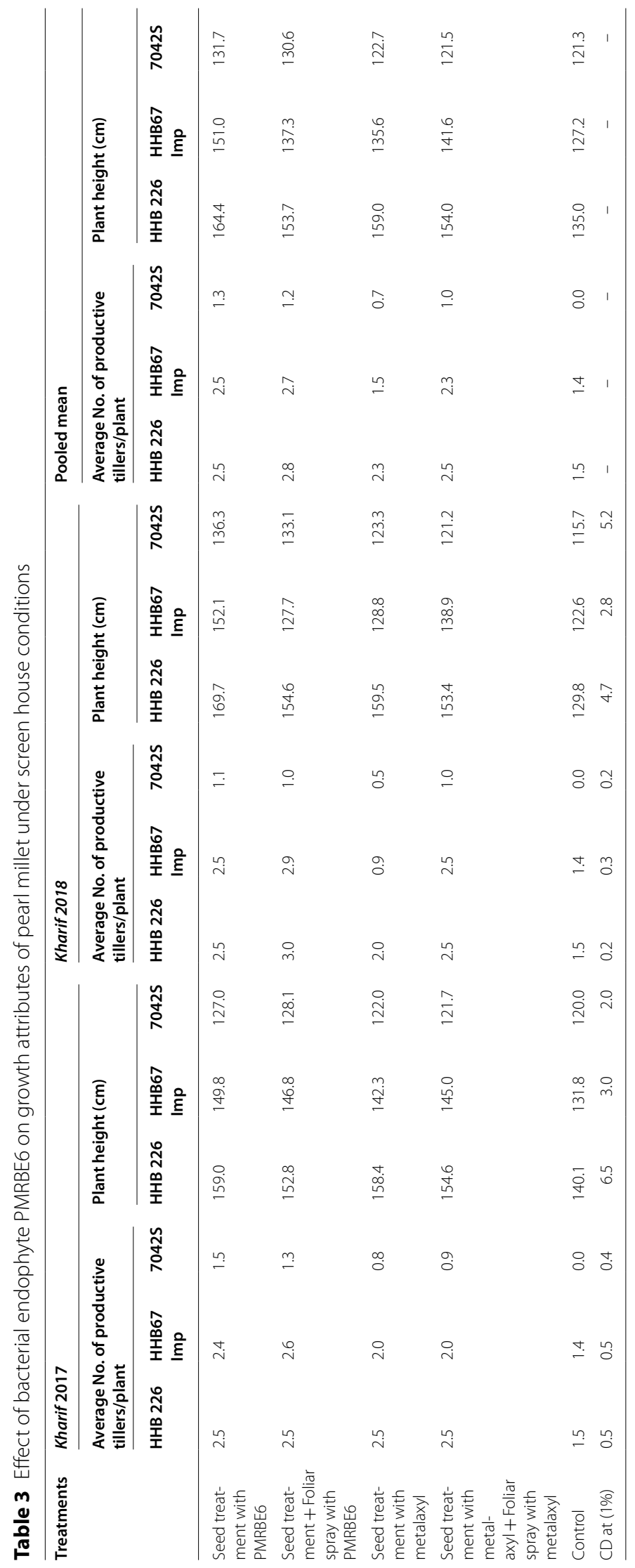




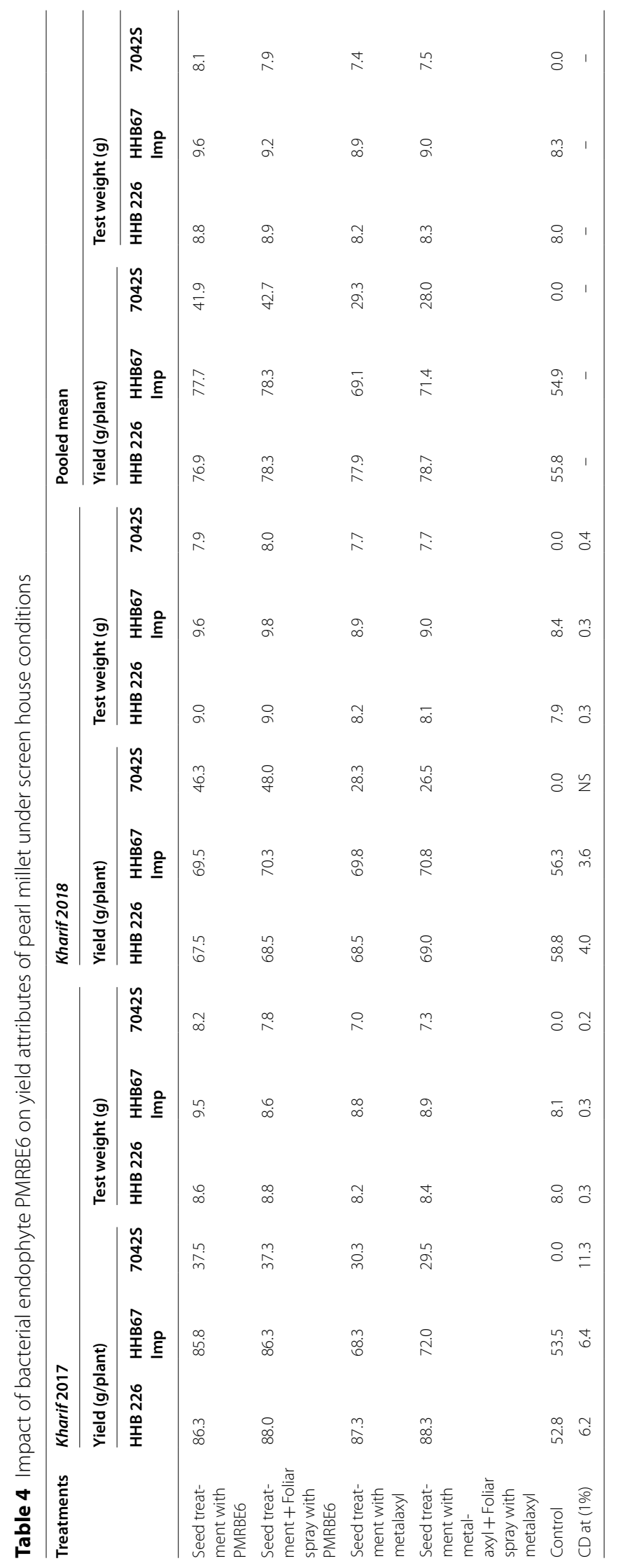


test weight of $9.6 \mathrm{~g}$ and $8.1 \mathrm{~g}$ on inoculation with isolate PMRBE6, respectively (Table 4).

\section{Discussion}

Pearl millet is prone to many diseases, and amongst them downy mildew is economically more important. Endophyte influence plant growth after establishment in a plant and provide resistance. Endophyte bacteria can promote plant growth and health by other mechanisms like siderophore production, cyanogenic potential and ACC deaminase activity. Siderophore are low molecular weight compounds with high iron chelating affinity and responsible for solubilization and transport of iron into bacterial cells. Iron is an essential mineral, and its sequestration by specific endophytic bacterial siderophores can make it available to plants under iron limiting conditions and also make it unavailable to pathogenic microbes, thereby affecting the extent of pathogenicity. In the present study, out of 30 pearl millet root bacterial endophytes, 16 isolates showed siderophore production ability as indicated by development of orange halo zone on CAS medium amended with ferric chloride exhibiting the suitability for biocontrol activity. Siderophore production ability in endophytic bacteria isolated from various crops has also been reported by different researchers. Joshi et al. (2018) isolated 10 bacterial cultures from roots, stem and leaves of Ocimum sanctum and Aloe vera and reported siderophore production ability in 3 isolates. Similarly, Etminani and Harighi (2018) reported that out of 10 isolates retrieved from the leaves and stems of healthy wild Pistachio trees, 5 isolates, viz. $\mathrm{Pb} 1, \mathrm{~Pb} 71, \mathrm{~Pb} 78, \mathrm{Sp} 15$ and Bp108, were able to produce siderophores.

Bacterial endophytes produce hydrocyanic acid which acts as an inducer of resistance and constitutes a mechanism of defence against pathogens in plants. This volatile compound inhibits the electron transports, disrupts the energy supply to cells, thus ultimately leading to death of the pathogens (Aarab et al. 2015). Screening of pearl millet root bacterial endophytes for $\mathrm{HCN}$ production revealed that 3 isolates were able to produce $\mathrm{HCN}$ along with siderophore production potential. The results were in corroboration to the findings of Padder et al. (2017) that amongst 81 endophytes isolated from root samples of brown sarson (Brassica rapa L.), 15 endophytic isolates produced $\mathrm{HCN}$.

Ethylene is overproduced in plants as a result of wide range of biotic and abiotic stresses. In all higher plants, 1 -aminocyclo propane-1carboxylate (ACC) is the precursor of plant hormone ethylene. Some bacterial endophytes have the capability to produce ACC deaminase enzyme, which catalyses the degradation of ACC into $\alpha$-ketobutyrate and ammonia, thereby reducing stress induced ethylene level in plants and also reduce negative consequences of ethylene on plant growth and development (Sun et al. 2009). In the present study, out of 30 endophytic bacterial isolates, 9 isolates (30\%) showed good ACC deaminase activity. The results were in close agreement with the findings of Hynes et al. (2008) that out of 563 bacteria originating from pea, lentil and chickpea roots, 5\% isolates showed ACC deaminase activity. Similarly, Etesami et al. (2014) isolated 200 bacterial isolates from rhizospheric soil and roots, nodules of berseem clover plants and found that only 72 isolates were positive for ACC deaminase production.

The bacterial isolate PMRBE6 found promising for different biocontrol attributes was identified as B. subtilis strain PD4 based on morphological, biochemical and molecular characterization (Accession no. MN400209). Different species of Bacillus have also been reported as endophytes for biocontrol activity in different crop disease management. The results are in close agreement with findings of Kumar et al. (2016).

Downy mildew incidence at 30 and 60 DAS was recorded minimum on inoculation of HHB 226, HHB67 Imp and $7042 \mathrm{~S}$ seeds with isolate PMRBE6 and with seed treatment + foliar spray with isolate PMRBE6. The results were in accordance with findings of Chandrashekhra et al. (2007) that endophytic bacteria showed significant growth promoting effects on pearl millet crop and exhibited resistance against downy mildew caused by Sclerospora graminicola under pot house conditions with disease reduction ranging from 15 to $53 \%$.

Seed treatment with endophytic bacteria was reported to improve vegetative growth parameters such as plant height, fresh weight, dry weight and number of basal tillers in pearl millet over control (Chandrashekhra et al. 2007). Similarly, in the present study, inoculation of pearl millet seeds with isolate PMRBE6 showed positive effect on various growth parameters of pearl millet.

\section{Conclusions}

The pearl millet bacterial root endophyte PMRBE6, identified as B. subtilis strain PD4, exhibiting various plant growth promoting traits in the present study stands out as possible candidate for usages as biocontrol agent against S. graminicola, the causal of pearl millet downy mildew. 


\section{Abbreviations}

CD: Critical difference; MR: Methyl red; VP: Voges-proskauer.

\section{Acknowledgements}

Authors are highly thankful to Dean Post Graduate Studies and Head Department of Plant Pathology, CCS Haryana Agricultural University, Hisar (Haryana), India, for providing facilitation to carry out research work.

\section{Authors' contributions}

PS contributed to methodology, data collection, statistical analysis, writingoriginal manuscript. KR contributed to conceptualization, planning, conductance, monitoring, writing-review and editing. LW contributed to endophyte identification, review and editing and AK contributed to conceptualization, planning, supervision, examination of pathogen prevalence. All authors proofread and approved the final manuscript.

\section{Funding}

No special funding was obtained for this study.

\section{Availability of data and materials}

All data generated or analysed in this study are available in this manuscript.

\section{Declarations}

Ethics approval and consent to participate

Not applicable.

\section{Consent for publication}

This study does not contain any individual person's data and authors consent for publication.

\section{Competing interests}

The authors declare that they have no competing interests.

\section{Author details}

'Department of Plant Pathology, College of Agriculture, CCS Haryana Agricultural University, Hisar, Haryana Pin 125 004, India. ${ }^{2}$ Department of Microbiology, COBS\&H, CCS Haryana Agricultural University, Hisar, Haryana Pin 125 004, India.

Received: 9 June 2021 Accepted: 4 September 2021

Published online: 17 September 2021

\section{References}

Aarab S, Ollero FJ, Megías M, Laglaoui A, Bakkali M, Arakrak A (2015) Isolation and screening of bacteria from rhizospheric soils of rice fields in Northwestern Morocco for different plant growth promotion (PGP) activities an in vitro study. Int J Curr Microbiol Appl Sci 4(1):260-269

Alstrom S, Burns RG (1989) Cyanide production by rhizobacteria as a possible mechanism of plant growth inhibition. Biol Fert Soils 7:232-238. https:// doi.org/10.1007/BF00709654

Bai Y, Aoust FD, Smith D, Driscoll B (2002) Isolation of plant-growth promoting Bacillus strains from soybean root nodules. Can J Microbiol 48(3):230-238. https://doi.org/10.1139/w02-014

Banik A, Mukhopadhaya SK, Dangar TK (2016) Characterization of N2-fixing plant growth promoting endophytic and epiphytic bacterial community of Indian cultivated and wild rice (Oryza spp.) genotypes. Planta 243(3):799-812. https://doi.org/10.1007/s00425-015-2444-8

Berg G (2009) Plant microbe interactions promoting plant growth and health: perspectives for controlled use of microorganisms in agriculture. Appl Microbiol Biotechnol 84(1):11-18. https://doi.org/10.1007/ s00253-009-2092-7

Chandrashekhara NS, Deepak SA, Amruthesh KN, Shetty NP, Shetty HS (2007) Endophytic bacteria from different plant origin enhance growth and induce downy mildew resistance in pearl millet. Asian J Plant Pathol 1:1-11. https://doi.org/10.3923/ajppaj.2007.1.11
Etesami H, Hosseini HM, Alikhani HA (2014) In planta selection of plant growth promoting endophytic bacteria for rice (Oryza sativa L.). I Soil Sci Plant Nutr 14(2):491-503. https://doi.org/10.4067/S0718-95162014005000039

Etminani F, Harighi B (2018) Isolation and identification of endophytic bacteria with plant growth promoting activity and biocontrol potential from wild pistachio trees. The Plant Pathol J 34(3):208-217. https://doi.org/10.5423/ PPJ.OA.07.2017.0158

Holt JG, Krieg NR, Sneath PHA, Staley JT, Williams ST (1994) Bergey's manual of determinative bacteriology, 9th edn. The Williams and Wilkins Co, Baltimore

Hynes RK, Leung GCY, Hirkala DLM, Nelson LM (2008) Isolation, selection and characterization of beneficial rhizobacteria from pea, lentil and chickpea grown in western Canada. Can J Microl 54(4):248-258. https://doi.org/10. 1139/w08-008

Joshi S, Singh A, Prasad B (2018) Enzymatic activity and plant growth promoting potential of endophytic bacteria isolated from Ocimum sanctum and Aloevera. Int J Curr Microl Appl Sci 7(6):2314-2326. https://doi.org/10. 20546/ijcmas.2018.706.277

Kumar A, Singh R, Yadav A, Giri DD, Singh PK, Pandey KD (2016) Isolation and characterization of bacterial endophytes of Curcuma longa L. 3 Biotech 6(1):60. https://doi.org/10.1007/s13205-016-0393-y

Liu XY, Dou GM, Ma YC (2016) Potential of endophytes from medicinal plants for biocontrol and plant growth promotion. J Gen Plant Pathol 82:165-173. https://doi.org/10.1007/s10327-016-0648-9

Padder SA, Bhat ZA, Dar GH, Mohiddin FA (2017) Impact of plant growth promoting bacterial root Endophytes on growth and nutrient status of brown sarson (Brassica rapa L.). Int J Pure Appl Biosci 5(2):638-651. https://doi.org/10.18782/2320-7051.2668

Penrose DM, Glick BR (2003) Methods for isolating and characterizing ACC deaminase- containing plant growth-promoting rhizobacteria. Physiol Plants 118(1):10-15. https://doi.org/10.1034/j.1399-3054.2003.00086.x

Prakash J, Arora NK (2019) Phosphate-solubilizing Bacillus sp. enhances growth, phosphorus uptake and oil yield of Mentha arvensis L. 3 Biotech. 4:126. https://doi.org/10.1007/s13205-019-1660-5

Quadt-Hallmann A, Kloepper JW, Benhamou N (1997) Bacterial endophytes in cotton: mechanisms of entering the plant. Can J Microbiol 43(6):577-582. https://doi.org/10.1139/m97-081

Rosenblueth M, Martínez-Romero E (2004) Rhizobium etli maize populations and their competitiveness for root colonization. Arch Microbiol 181(5):337-344. https://doi.org/10.1007/s00203-004-0661-9

Ryan RP, Germaine K, Franks A, Ryan DJ, Dowling DN (2008) Bacterial endophytes: recent developments and applications. FEMS Microbiol Lett 278(1):1-9. https://doi.org/10.1111/j.1574-6968.2007.00918.x

Sandhya V, Shrivastava M, Ali SZ, Prasad VSSK (2017) Endophytes from maize with plant growth promotion and biocontrol activity under drought stress. Russ Agric Sci 43:22-34. https://doi.org/10.3103/S10683674170101 65

Schwyn B, Neilands JB (1987) Universal chemical assay for the detection and determination of siderophore. Ann Biochem 160:47-56. https://doi.org/ 10.1016/0003-2697(87)90612-9

Souza RD, Meyer J, Schoenfeld R, Costa PBD, Passaglia LMP (2015) Characterization of plant growth-promoting bacteria associated with rice cropped in iron stressed soils. Ann Microbiol 65:951-964. https://doi.org/10.1007/ s13213-014-0939-3

Sun Y, Cheng Z, Glick BR (2009) The presence of a 1-aminocyclopropane1-carboxylate (ACC) deaminase deletion mutation alters the physiology of the endophytic plant growth promoting bacterium Burkholderia phytofirmans PsJN. FEMS Microbiol Lett 296(1):131-136. https://doi.org/ 10.1111/j.1574-6968.2009.01625.x

Wang SL, Wang WT, Jin ZG (2013) Screening and diversity of plant growth promoting endophytic bacteria from peanut. Afr J Microbiol Res 7(10):875884. https://doi.org/10.5897/AJMR12.1500

\section{Publisher's Note}

Springer Nature remains neutral with regard to jurisdictional claims in published maps and institutional affiliations. 